\title{
Brominated Flame Retardants in the Environment: Their Sources and Effects (a Review)
}

\author{
P. MIKULA, Z. SVOBODOVÁ \\ Faculty of Veterinary Hygiene and Ecology, University of Veterinary and
}

Pharmaceutical Sciences Brno, Czech Republic

Received April 12, 2006

Accepted June 30, 2006

\begin{abstract}
Mikula P., Z. Svobodová: Brominated Flame Retardants in the Environment: Their Sources and Effects (a Review). Acta Vet. Brno 2006, 75: 587-599.

Brominated flame retardants (BFRs) are organic substances frequently used in many industries. The most important group within BFRs are polybrominated diphenyl ethers (PBDEs). Because they persist in the environment, accumulate in food chains and have toxic effects, they are a potential health risk both for animals and humans. Polybrominated diphenyl ethers may disrupt processes of hormonal regulation in living organisms by reducing thyroxine concentrations in the plasma of the exposed individuals. In vitro studies have demonstrated the ability of these substances to bind to estrogen and androgen receptors. Tests on rodents have also demonstrated neurotoxicity of some of the PBDEs. Although industrial use of PBDEs is now regulated to a large extent, PBDEs have already been detected in areas with no apparent industrial load, e.g. in Greenland. This article presents an overview of BFRs-related issues with a particular emphasis on PBDEs, describes toxic effects of those substances and their metabolism in living organisms, and discusses issues related to the incidence of PBDEs in the environment.
\end{abstract}

BFRs, polybrominated diphenyl ethers, tetrabromobisphenol A, environmental endocrine disruptors, toxicity, metabolism

A large number of chemical substances have recently been under an intensive scrutiny because of their possible adverse health effects on both humans and animals. These substances include the so-called brominated flame retardants (BFRs). They are substances used in a number of industries in the manufacture of polymers and synthetic resins to reduce the risk of fires. Brominated flame retardants are used in building materials (polymer foams, thermal insulations), electric cable insulation, consumer electronics (TV sets, VCRs, computers) and household furnishings (furniture upholstery, carpets, etc.). Brominated flame retardants contain different numbers of bromine atoms which are released from the polymer matrix by heat. They then neutralize energy-rich radicals produced during the combustion process, thus making it more difficult for the process of combustion to continue. Depending on the flame retardant bond in polymer, two groups of BFRs are distinguished. While reactive flame retardants are incorporated into polymer through covalent bonds, additive brominated flame retardants are loosely dispersed in the polymer. Tens or even hundreds of thousands of tonnes of BFRs are produced in the world every year (Table 1). The most frequently used BFRs are tetrabromobisphenol A (TBBPA), commercially produced mixtures of polybrominated diphenyl ethers (PBDEs) and hexabromocyclododecane (HBCD). These substances are released to the environment as a result of extensive industrial exploitation of BFRs. From the point of view of possible negative effects on human and animal health, a lot of attention has been devoted mainly to PBDEs, which may persist in the environment for extended periods of time, and are accumulated in living organisms. Polybrominated diphenyl ethers are highly stabile lipophilic substances that resemble polychlorinated biphenyls (PCBs) in their structure, and physical and

Address for correspondence:

Přemysl Mikula

University of Veterinary and Pharmaceutical Sciences

Department of Veterinary Public Health and Toxicology

Palackého 1-3, 61242 Brno, Czech Republic
Phone: +420541562780

Fax: +420 541562790

e-mail:pmikula@vfu.cz

http://www.vfu.cz/acta-vet/actavet.htm 
Table 1. Total market demand of different BFRs by region in 2001 [in metric tons] (BSEF 2005)

\begin{tabular}{|l|r|r|r|r|r|}
\hline & Americas & Europe & \multicolumn{1}{|c|}{ Asia } & Rest of the world & Total market demand \\
\hline TBBPA & 18000 & 11600 & 89400 & 600 & 119700 \\
HBCD & 2800 & 9500 & 3900 & 500 & 16700 \\
decaBDE & 24500 & 7600 & 23000 & 1050 & 56100 \\
octaBDE & 1500 & 610 & 1500 & 180 & 3790 \\
pentaBDE & 7100 & 150 & 150 & 100 & 7500 \\
total BFRs & 53900 & 29460 & 117950 & 2430 & 203790 \\
\hline
\end{tabular}

chemical characteristics. The burning of PBDEs may produce toxic polybrominated dibenzodioxins (PBDDs) and dibenzofurans (PBDFs). Depending on the degree of substitution of the two benzene nuclei with bromine atoms, up to 209 BDE congeners may be produced. The distribution of PBDE congeners in the environment is related to the use of PBDE-based BFRs by the industry. Nowadays, the most frequently used PBDE-based products are commercially produced decaBDE mixtures. In the past, octaBDE and pentaBDE mixtures were extensively used. The use of these BFRs has, however, been banned in Europe, and both penta-and octaBDE mixtures are used in larger quantities only in certain states of the USA (Darnerud et al. 2001; BSEF 2005).

\section{Toxic effects of BFRs}

It has been established that BFRs, and PBDEs in particular, may negatively affect processes of hormonal regulation in living organisms and they are therefore classified as the so-called environmental endocrine disruptors (EEDs).

Numerous experiments in rodents have proven thyroid hormone homeostasis disruption in the serum and plasma of individuals exposed to various doses of PBDEs ( $\mathrm{Zhou}$ et al. 2001; Zhou et al. 2002; Hallgren et al. 2001; Fowles et al. 1994). It is hypothesized that it may occur as a result of direct damage to the thyroid gland, disruption of thyroid hormones metabolism, or, possibly, as a result of a disruption in hormone transport to target tissues. Zhou et al. (2001) studied the effects of commercially produced PBDE mixtures. In their studies involving female rats exposed to DE-71 (pentaBDE) and/or DE-79 (octaBDE) mixtures for 4 days, the authors demonstrated decreased concentrations of serum thyroxine $\left(\mathrm{T}_{4}\right)$ in exposed rats. They also demonstrated induced activity of uridinediphosphate-glucuronosyltransferase (UDPGT) enzyme, which participates in $\mathrm{T}_{4}$ catabolism in the liver. In rats exposed to DE-83R (decaBDE) mixture, no decrease in serum $\mathrm{T}_{4}$ concentrations was demonstrated, neither did any of the experimental groups exposed to PBDEs mixtures demonstrate any changes in thyroid stimulating hormone (TSH) concentrations. Furthermore, results of a subsequent study indicate that an exposure of female rats to a DE-71 mixture during pregnancy will not only decrease $\mathrm{T}_{4}$ concentrations in the females but also in their offspring. That decrease, however, was only temporary and serum $\mathrm{T}_{4}$ concentrations were restored relatively soon after the end of exposure. At the same time, Zhou et al. (2002) also proved that exposure to DE-71 did not cause any decrease in triiodothyronine concentrations $\left(\mathrm{T}_{3}\right)$ in rats ( $\mathrm{Zhou}$ et al. 2002). Decreased serum $\mathrm{T}_{4}$ concentrations with no concurrent alterations in serum $\mathrm{T}_{3}$ concentrations can be explained either by an increase in the transformation of $\mathrm{T}_{4}$ into $\mathrm{T}_{3}$ in tissues as a result of an increased deiodinase enzyme activity, or by a relatively higher degree of $\mathrm{T}_{4}$ catabolism or clearance in the liver compared with $\mathrm{T}_{3}$. Results similar to those of Z hou et al. $(2001,2002)$ were also obtained by Fowles et al. (1994) and Hallgren et al. (2001). The ability of BFRs to bind to the transport protein transthyretin (TTR) in vitro has also been studied by Meerts et al. (2000). The authors found that the highest ability to compete with $\mathrm{T}_{4}$ for the transport protein TTR was demonstrated by TBBPA and pentabromophenol (PBP). Some hydroxylated 
PBDE metabolites (or, rather, derivatives) were also found capable of binding to TTR, while unhydroxylated PBDEs do not bind to TTR. The exact mechanism of thyroid hormone homeostasis disruption remains unclear. It is assumed that more than one factor may play a role in that process.

Possible adverse effects of BFRs on processes of hormonal regulation involving sex steroid hormones have also been examined. In vitro experiments with cell cultures have shown that some PBDE congeners, and especially their hydroxylated derivatives, and some brominated bisphenols, are able to bind to estrogen receptors (ER). BFR competition as an ER ligand with the natural ligand of that receptor estradiol may produce estrogenic or antiestrogenic effects. If the binding of BFRs to ER triggers a cascade of events whereby the $\mathrm{ER} \times \mathrm{BFR}$ complex interacts with estrogen responsive elements (EREs) in promoter regions of target genes and induces transcription of those genes, then we can speak of estrogenic effect of the substance examined. If, however, the binding of BFRs to ER fails to trigger this cascade of events and, moreover, the use of the natural ligand, estradiol, is impeded (reduced ER availability), we then speak of an anti-estrogenic effect. Of the PBDE congeners examined by Meerts et al. (2001), the highest ability to bind to ER was found in BDE-100, BDE-75 and BDE-51. This finding is of particular interest because the BDE-100 congener (the most potent ER ligand) is one of the most abundantly found PBDE congeners in the environment. Studies of brominated bisphenols have shown that bisphenols with the greatest estrogenic potential are low-brominated bisphenols (monobromobisphenol A and dibromobisphenol A), which has also been corroborated by Samuelsen et al. (2001). Estrogenic effects of BFRs in vitro have also been examined by Nakari and Pesala (2005). The authors tested the effects of selected congeners of polybrominated biphenyls (PBBs) and PBDEs and commercially produced mixture of brominated biphenyls with six bromine atoms, Firemaster BP-6 ${ }^{\mathrm{TM}}$. It is interesting to note that while all BFRs with the exception of Firemaster BP- $6^{\mathrm{TM}}$ induced vitellogenin production in cell cultures of rainbow trout (Oncorhynchus mykkis) hepatocytes, i.e. elicited an estrogenic response, they had no such effect on yeast cultures containing human recombinant ER receptor. The authors also noted that estrogenic response intensity increased with an increase in the number of bromine atoms in PBDEs. Besides the ability of BFRs to bind to the ER receptor, the ability of the commercially produced mixture DE-71 (pentaBDE) to bind to the androgen receptor (AR) has also been examined. Stoker et al. (2005) drew attention to the fact that male rats exposed to the DE-71 mixture showed symptoms indicating an antiandrogenic effect of the mixture. The symptoms included delayed onset of puberty in the rats exposed, suppressed growth of androgen-dependent tissues (ventral prostate gland, seminal vesicles) and delayed preputial separation. The authors confirmed the antiandrogenic effect in an in vitro study using cell culture of cytosol of rat ventral prostate cells.

Besides the above toxic effects of brominated flame retardants, a relationship between an exposure of rodents to PBDEs and disturbances in their behaviour has also been demonstrated. Eriks s on et al. (2002) and Viberg et al. (2002, 2003ab) noted that neonatal exposure to some PBDE congeners impairs spontaneous behaviour, learning and memory of exposed mice. The disturbances become manifest only after the experimental animals reach adulthood, and then they become more pronounced as the animals grow older. Similar results have also been obtained by Branchi et al. (2003) and Kuriyama et al. (2005). Behavioural disturbances in rodents will occur if animals are exposed to PBDEs during the critical period of their brain development. The exact mechanism of neurotoxic action has not been completely clarified yet. It is assumed that the reason for PBDE neurotoxicity might lie in the above-mentioned disruption of thyroid hormone homeostasis and the consequent decline in $\mathrm{T}_{4}$ concentrations in the serum of experimental animals. Viberg et al. (2002, 2003b) believe that the more probable cause is the disruption of the cholinergic 
neurotransmitter system consequent upon a decrease in the number of nicotine receptors in the brain hippocampus.

Another adverse effect of BDE-99 in rodents mentioned by Kuriy a ma et al. (2005) are spermatogenesis disorders in males. The authors noted that an exposure of pregnant female rats to 60 and $300 \mathrm{ng} / \mathrm{g}$ body weight during the intrauterine developmental stage of their foetuses causes a decrease of sperm and spermatid counts without any concurrent deterioration in their quality in their male offspring. It needs to be emphasized that the study proved toxic effects of PBDEs even at very low exposure doses. This fact should be taken into account when health risks of BFRs for humans are assessed.

It seems very likely that many toxic effects of BFRs may be linked to their affinity to the so-called Ah receptor (AhR). This receptor belongs to the family of regulatory proteins, and after the binding of its ligand or agonist (e.g. 2,3,7,8 - tetrachlorodibenzo- $p$ - dioxin (TCDD)) it produces a heterodimer with the AhR nuclear translocator (ARNT). The resulting heterodimer penetrates further into the cell nucleus where it integrates with the so-called xenobiotic response elements (XREs) and triggers the expression of target genes. An induction of expression of these genes produces the synthesis of oxidation enzymes of stage 1 of xenobiotics detoxication. In this way, CYP1A1, CYP1A2 and some other systems are induced. It is hypothesized that many toxic effects of TCDD (carcinogenicity, teratogenicity, hepatotoxicity, immunosuppression and reproduction toxicity) are mediated through the AhR (Safe 2001; Reen et al. 2002). BFR affinity to the AhR has been tested in several in vitro studies. Chen and Bunce (2003) demonstrated that some PBDE congeners (particularly BDE-119, BDE-77 and BDE-126) were able to bind to the AhR in vitro. The authors also proved the antagonistic action of those congeners to TCDD. Kuiper et al. (2004) studied the effects of BFRs on common carp (Cyprinus carpio) hepatocytes cell culture. The extent of CYP1A1 system induction was expressed by means of measuring ethoxyresorufin-O-deethylase (EROD) activity. The authors stated that some PBDE congeners (BDE-47, BDE-99 and BDE-153) inhibit EROD activity induced by TCDD and thus act as AhR-antagonists. The ability of BFRs to act through the AhR has also been examined in vivo. It is interesting to note that while in vitro studies all mention the AhRantagonistic effects of BFRs examined, in vivo studies have produced contradictory results. In their studies with Atlantic salmon (Salmo salar) and/or rainbow trout (Oncorhynchus mykkis), B oon et al. (2002) and Holm et al. (1994) respectively, investigated the effects of exposure to commercial mixtures pentaBDE and octaBDE. The authors found no deviations in the EROD activity. Exposure of fish to BFRs has also been studied in vivo by Ronis z et al. (2004). The authors noted that trout exposed to intraperitoneally administered TBBPA showed relatively small but nevertheless significant decreases in the EROD activity. The AhR-antagonistic action has also been proven in tests with HBCD. A simultaneous exposure of fish to HBCD and the natural AhR ligand $\beta$-naphtoflavon caused a decrease in EROD activity compared to a group of fish exposed to $\beta$-naphtoflavon only.

\section{The metabolism of BFRs}

Any assessments of health risks for humans or animals by exposure to BFRs must take into account the issue of metabolism of those substances in living organisms. Metabolism of PBDEs has been investigated in a large number of studies. Results of rodent studies have confirmed the existence of different mechanisms in the metabolism of different PBDE congeners.

Metabolic processes in rodents exposed to the BDE-47 congener have been investigated by Örn and Klasson-Wehler (1998) and Staskal et al. (2005). They found that orally administered BDE-47 congener is relatively readily absorbed from the gastrointestinal tract. In mice, the unabsorbed portion of BDE-47 made up about $7 \%$ of the dose administered. 
In rats, the unabsorbed portion of BDE-47 was only 5\% of the dose administered (Örn and Klasson-Wehler 1998). The BDE-47 congener absorbed in the GIT is then distributed to tissues. The highest BDE-47 congener concentrations 5 days after its oral administration were found in lipid-rich tissues (adipose tissue, skin, liver). It has also been ascertained in mice experiments that the urine-excreted proportion of BDE-47 increases and the faecesexcreted proportion of BDE-47 decreases with an increase in the exposure dose (Staskal et al. 2005). In rats, BDE-47 metabolism mechanism is similar to that of mice, only much slower. Staskal et al. (2005) noted that approximately $65-81 \%$ of BDE-47 orally administered to male mice were excreted in urine and faeces within 5 days of administration. Örn and Klas son-Wehler (1998) found that while mice excreted $20 \pm 4 \%$ and $33 \pm 0.4 \%$ of BDE-47 in faeces and urine, respectively, within the first 5 days of its oral administration, rats excreted only about $14 \pm 3 \%$ of the congener in faeces and $<0.5 \pm 0.02 \%$ in urine over the same period of time. In addition to BDE-47, some other hydroxylated BDE-47 metabolites were also detected in blood plasma and tissues of experimental animals (Örn and Klasson-Wehler 1998).

The congener BDE-209 metabolism is different. Compared with BDE-47, congener BDE209 has a significantly higher molecular weight. That makes its absorption in the GIT very difficult. In their experiments with rats, $\mathrm{S}$ and holm et al. (2003) found that congener BDE209 availability was about $26 \%$ of the orally administered dose. The relatively low absorption rate has been confirmed by Mörck et al (2003), who found that at least $10 \%$ of the orally administered ${ }^{14} \mathrm{C}$-labelled BDE-209 congener was absorbed. The highest concentrations of BDE-209 seven days after application were detected in the adrenal gland, kidneys, heart and liver, while BDE-209 concentrations in the adipose tissue of the exposed animals were surprisingly relatively low. Mörck et al (2003) highlighted the fact that a relatively large number of metabolites of the substance administered were detected in the faeces of experimental animals. Metabolic transformation of BDE-209 has also been confirmed by Sandholm et al. (2003), who demonstrated the presence of hydroxyoctaBDE, hydroxy-nonaBDE and hydroxy-methoxy-hexaBDE metabolites in the plasma of animals exposed to BDE-209.

The metabolism of PBDEs has also been studied in fish. It has been demonstrated that an exposure of the common carp (Cyprinus carpio) to the BDE-209 congener does not produce any major accumulation of the congener in fish tissues. In spite of that, 7 penta- to octaBDE congeners were still detected in tissues of the exposed fish (length of exposure 60 days, BDE-209 concentration in feeds $940 \mathrm{ng} / \mathrm{g}$ ) 40 days after the period in which the fish were fed the feed tested (Stapleton et al. 2004a). Debromination of some PBDE congeners has been corroborated in a number of other studies of PBDE metabolism in carp (Stapleton et al. 2004bc). Some other authors also agreed that the reason for exceptionally high accumulation efficiencies of certain PBDE congeners in fish lied in the debromination of PBDE congeners with a higher number of bromine atoms (Tomy et al. 2004; Is o sa ari et al. 2005). An interesting phenomenon has been described in the common carp. Although the BDE-99 congener is one of dominant congeners of commercially produced pentaBDE mixtures and one of the most frequently detected congeners in living organisms, there is no accumulation of this congener in the liver or any other tissues of carp with the exception of intestines (Stapleton et al. 2004b). Stapleton et al. (2004b) hypothesize that congener BDE-99 debromination may take place in the intestine as a result of the activity of bacterial microflora or of endogenic enzyme systems there. These assumptions are in agreement with findings from field studies. Johnson and Olson (2001) reported extremely low accumulation of pentaBDE congeners in tissues of the common carp (Cyprinus carpio) and the large-scale sucker (Catostomus macrocheilus) compared with other species of fish, which suggests their increased ability to metabolize BDE-99. 
Some methoxylated PBDE derivatives have been detected in tissues of fish and cetaceans (Kierkegaard et al. 2004; Pettersson et al. 2004). The source of these methoxylated PBDEs remains unclear. It is very unlikely that these PBDE derivatives are of anthropogenic origin, nor are they assumed to be metabolic products of those animals. It is, however, possible that they are products of the activity of bacteria, algae or marine sponges. Kierkegaard et al. (2004) hypothesized that methoxylated PBDE derivatives may be the outcome of biogenic production independent on the degree of water eutrophication.

TBBPA metabolism has also been investigated in a number of studies. In a test in which $2.0 \mathrm{mg} / \mathrm{kg}$ bodyweight of ${ }^{14} \mathrm{C}$ - labelled tetrabromobisphenol A (TBBPA) were administered orally to rats, at least $92 \%$ of the substance tested were eliminated from the body in 72 hours. The principal elimination pathway are faeces that are responsible for the elimination of about $91.7 \%$ of the ${ }^{14} \mathrm{C}$-TBBPA administered, while the proportion of ${ }^{14} \mathrm{C}$-TBBPA dose excreted in urine is very small (about $0.3 \%$ ). Enterohepatic circulation of ${ }^{14} \mathrm{C}$ - TBBPA is indicated by the high amount of radioactivity (about $71.3 \%$ of the dose administered) found in the bile of bile-duct canullated rats. In addition to TBBPA itself, three metabolites were detected in the bile of experimental animals. They most probably were conjugates of TBBPA and glucuronic or sulphuric acid (Hakk et al. 2000). In their TBBPA metabolism monitoring study in rats, Szymańska et al. (2001) reached similar conclusions as Hakk et al. (2000) when they found that most of intraperitoneally administered TBBPA had been excreted in faeces. The fundamental difference established in the two studies is the rate of TBBPA metabolism. While Hakk et al. (2000) were able to demonstrate the retention of only about $2 \%$ TBBPA in tissues of experimental rats 72 hours after oral administration of TBBPA, Szymańska et al. (2001) found as much as 15 - 20\% of the TBBPA dose still in the body 72 hours after its intraperitoneal administration.

\section{Brominated flame retardants in the environment}

The most problematic BFRs from the point of view of their occurrence in the environment are PBDEs. Because they are highly stable substances with only a limited degradation capability, PBDEs are ubiquitous in the environment. The most frequently detected PBDE congeners in living organisms include, first and foremost, congeners BDE-47, BDE-99, BDE-100 and BDE-153, BDE-154 and BDE-183, the most important congener in sediments being the congener BDE-209.

It is sediment that represents the principal source of biota contamination in the aquatic ecosystems. Sediment contamination with PBDEs depends primarily on the amount of industrial pollution in the area. High PBDE concentrations were found, e.g., in sediment samples collected in the Scheldt estuary in Netherlands. PBDE concentrations found by Verslycke et al. (2005) in sediments from that area ranged between 272 and 1664 $\mathrm{ng} / \mathrm{g}$ dry weight $(\mathrm{dw})$. It is interesting to note that while the maximum total concentration of the sum of 14 PBDE congeners with relatively lower bromine atoms was $22 \mathrm{ng} / \mathrm{g} \mathrm{dw}$, BDE-209 congener concentrations were many times higher. Other European locations with significant PBDE concentrations in sediments were the Tees estuary and the rivers Skerne and Calder in the UK, respectively (A1lchin et al. 1999). Probably the highest contamination level in Europe was found in sediment samples collected in 1995 downstream of a waste-water treatment plant at the Calder river, where $3190 \mathrm{ng} / \mathrm{g} \mathrm{dw}$ of DE-83 (i.e. commercially manufactured decaBDE compound) were detected. Because no PBDEs were detected in sediment samples collected at the control location, it may be concluded that sediment contamination in this case was again due to the presence of point sources of pollution (e.g. companies manufacturing or using PBDE-based products). One of the least contaminated locations in Europe, on the other hand, is the Danube delta, where no PBDEs were detected in any of the sediment samples collected there (Covaci et al. 2006). 
As in the case of sediments, PBDE concentrations detected in fish depend on the industrialization intensity in the region from which the fish come. Measuring concentrations of some PBDE congeners and HBCD in homogenized whole fish samples of bleak (Alburnus alburnus) from the Cinca river (Spain), Eljarrat et al. (2005) found the highest BFRs concentrations in adult fish caught immediately downstream of a highly industrialized region $(\Sigma$ PBDEs $=555 \mathrm{ng} / \mathrm{g}$ wet weight $[\mathrm{ww}], \mathrm{HBCD}=1501 \mathrm{ng} / \mathrm{g} \mathrm{ww})$, while very low BFR concentrations were found in fish caught in the upper reaches of the river, i.e. upstream of the site of possible contamination $(\Sigma \mathrm{PBDEs}=4.69 \mathrm{ng} / \mathrm{g} \mathrm{ww}, \mathrm{HBCD}<\mathrm{ld}$. [below the limit of detection]). Relatively lower concentrations of BFRs were detected in juvenile fish (e.g. mean concentrations in juvenile fish caught downstream of the highly industrialized region were $\Sigma$ PBDEs $=445 \mathrm{ng} / \mathrm{g}$ ww and $\mathrm{HBCD}=381 \mathrm{ng} / \mathrm{g} \mathrm{ww})$. Similar results were also reported by Allchin et al. (1999). PBDE concentrations in the liver of fish caught at the most contaminated sites in the UK were in hundreds of $\mathrm{ng} / \mathrm{g}$ ww (the maximum $\Sigma$ PBDE concentration found in the liver of a flounder (Platichthys flesus) caught in the Tees Bay was $1532 \mathrm{ng} / \mathrm{g} \mathrm{ww})$. PBDE concentrations in organisms depend to a large extent on the position of the organisms in the food chain. The highest PBDE concentrations were detected in predator fish (e.g. in wels, Silurus glanis), while PBDE concentrations found in tissues of herbivorous fish or omnivorous fish with a predominance of vegetable component in their diet (e.g. nose-carp, Chondrostoma regium) were markedly lower (Erdogrul et al. 2005).

PBDEs and HBCD are not a problem for the aquatic environment only, but are quite commonly detected also in the terrestrial environment. Investigating PBDEs and HBCD concentrations in eggs of wild peregrine falcons (Falco peregrinus) from Sweden and comparing them with PBDE and HBCD concentrations in eggs of birds of the same species living in captivity, Lindberg et al. (2004) found the highest overall concentrations of PBDEs and HBCD in the eggs of wild falcons from southern Sweden ( $\Sigma$ PBDEs $=2656$ $\mathrm{ng} / \mathrm{g}$ lipid weight [lw], HBCD $=250 \mathrm{ng} / \mathrm{g} \mathrm{lw}$ ). Concentrations of BFRs in the eggs of falcons living in captivity were relatively low ( $\Sigma$ PBDEs $=45.62 \mathrm{ng} / \mathrm{g} \mathrm{lw}, \mathrm{HBCD}<\mathrm{ld})$. The authors demonstrated relatively high BDE-209 congener concentrations in eggs of several falcons (430 ng/g lw max), which seems to corroborate the assumption that BDE-209 is available to phylogenetically higher animals. Studying PBDE concentrations in eggs of little owls (Athene noctua) from Belgium, Jaspers et al. (2005) found the mean concentration $\Sigma$ PBDEs $=150 \mathrm{ng} / \mathrm{g}$ lw $(29-570 \mathrm{ng} / \mathrm{g} \mathrm{lw})$. Of the seven PBDE congeners studied, the highest concentrations were detected in congeners BDE-99, BDE-153 and BDE-47. Relatively high concentrations of the congener BDE-183 were also found. This finding seems to corroborate the assumptions put forth by Law et al. (2003) to the effect that birds whose dietary specialization restricts them to the consumption of mainly terrestrial animals are, compared with birds consuming animals from aquatic environment, to a much greater extent exposed to PBDE congeners with a high number of bromine atoms from commercially produced octaBDE mixtures (Law et al. 2003).

\section{Human exposure to brominated flame retardants}

Because PBDEs may be a potential threat to human health, their concentrations in breast milk, blood serum and human adipose tissue have recently been under intensive scrutiny. Mean PBDE concentrations in breast milk samples from different geographical regions of the world are summarized in Table 2. Schecter et al. (2003) measured concentrations of 13 different PBDE congeners in human breast milk in the USA. The authors reported the mean $\Sigma$ PBDE value in their set of 47 mothers at $73.9 \mathrm{ng} / \mathrm{g}$ lipids (median $34 \mathrm{ng} / \mathrm{g} \mathrm{lw}$, range 6.2 - $419 \mathrm{ng} / \mathrm{g} \mathrm{lw}$ ). Compared to those figures, breast milk PBDE concentrations reported from Europe and Japan are much lower. The mean overall PBDE concentration found in breast milk in the Czech Republic by Kazda et al. (2004) was $2.21 \mathrm{ng} / \mathrm{g}$ lw. Mean $\Sigma$ PBDE concentrations reported by other authors range from 1.39 to $7.20 \mathrm{ng} / \mathrm{g} \mathrm{lw}$ (Akutsu et al. 
Table 2. Mean concentrations of PBDE congeners in human breast milk samples [ng/g lipid weight]

\begin{tabular}{|c|c|c|c|c|c|c|c|c|c|c|c|}
\hline Country & $\begin{array}{c}\text { Sampling } \\
\text { period }\end{array}$ & $\mathrm{n}$ & $\mathrm{Z}$ & $\begin{array}{c}\mathrm{BDE} \\
-28 \\
\end{array}$ & $\begin{array}{c}\mathrm{BDE} \\
-47\end{array}$ & $\begin{array}{c}\mathrm{BDE} \\
-99\end{array}$ & $\begin{array}{l}\text { BDE } \\
-100\end{array}$ & $\begin{array}{r}\text { BDE } \\
-153 \\
\end{array}$ & $\begin{array}{l}\text { BDE } \\
-154\end{array}$ & $\begin{array}{l}\text { BDE } \\
-183 \\
\end{array}$ & ¿PBDEs \\
\hline United States $^{\mathrm{a}}$ & 2001 & 47 & 13 & 2.40 & 40.80 & 14.00 & 8.20 & 5.30 & 0.76 & 0.13 & 73.90 \\
\hline Faroe Islands $^{\mathrm{b}}$ & 1998-1999 & $10^{\mathrm{P}}$ & 4 & NA & 1.70 & 1.00 & 1.00 & 3.60 & NA & NA & 7.20 \\
\hline Germany $^{\mathrm{c}}$ & 2004 & 8 & 7 & NA & 2.88 & 2.21 & 0.64 & 1.16 & 0.13 & 0.16 & 7.20 \\
\hline United Kingdom $^{\mathrm{d}}$ & $2001-2003$ & 54 & 15 & $0.3^{\mathrm{GM}}$ & $3^{\mathrm{GM}}$ & $0.9^{\mathrm{GM}}$ & $0.6^{\mathrm{GM}}$ & $1.4^{\mathrm{GM}}$ & $0.5^{\mathrm{GM}}$ & NA & $6.60^{\mathrm{GM}}$ \\
\hline Sweden ${ }^{\mathrm{e}}$ & 1996-1999 & 93 & 5 & NA & 2.35 & 0.62 & 0.38 & 0.60 & 0.07 & NA & 4.02 \\
\hline Norway ${ }^{\mathrm{f}}$ & 2003 & 32 & 6 & NS & NS & NS & NS & NS & NS & $\mathrm{NA}$ & 2.96 \\
\hline Spain (Catalonia) $)^{g}$ & 2002 & 15 & 15 & NS & NS & NS & NS & NS & NS & NS & 2.40 \\
\hline Czech Republic $^{\mathrm{h}}$ & 2003 & 103 & 9 & 0.15 & 0.86 & 0.28 & 0.17 & 0.19 & 0.11 & 0.28 & 2.21 \\
\hline Japan (Osaka) ${ }^{\mathrm{i}}$ & 2000 & $27^{\mathrm{P}}$ & 12 & 0.09 & 0.53 & 0.15 & 0.17 & 0.34 & 0.03 & 0.04 & 1.39 \\
\hline
\end{tabular}

$\mathrm{n}=$ number of samples; $\mathrm{z}=$ number of congeners tested; ${ }^{\mathrm{P}}$ pooled sample; $\mathrm{NA}=$ not analysed; NS $=$ not specified; ${ }^{\mathrm{GM}}$ geometric mean value; ${ }^{\mathrm{a}} \mathrm{Schecter}$ et al. (2003); ${ }^{\mathrm{b}} \mathrm{F}$ ängström et al. (2004); ${ }^{\mathrm{c}} \mathrm{Weber}$ and Hes eker (2004); ${ }^{\mathrm{d}}$ Kalantzi et al. (2004); ${ }^{\mathrm{e}}$ Lind et al. (2003); ${ }^{\mathrm{f}}$ Polder et al. (2004); g Schuhmacher et al. (2004); ${ }^{\mathrm{h}} \mathrm{Kazda}$ et al. (2003); ${ }^{i}$ Akutsu et al. (2003)

2003; Fangström et al. 2004; Kalantzi etal. 2004; Lind et al. 2004; Polder et al. 2004; Schuhmacher et al. 2004; Weber and Heseker 2004). Although different sizes of experimental groups and different numbers of PBDE congeners monitored make interpretation of results of these studies difficult, it is clear that people in the USA suffer from much greater exposure to polybrominated diphenyl ethers than people in Europe, where the exposure is far less serious. This has been confirmed by studies of PBDEs concentrations in human blood serum and plasma. Whereas overall PBDEs concentrations in the blood serum of American women ranged from 15 to $580 \mathrm{ng} / \mathrm{g}$ lw (median $37 \mathrm{ng} / \mathrm{g} \mathrm{lw}$ ) (Mazdai et al. 2003), PBDEs concentrations in the blood plasma of Swedish women were in the $0.71-8.39 \mathrm{ng} / \mathrm{g}$ lw range (median $2.07 \mathrm{ng} / \mathrm{g}$ lw) (Meiron y té-Guvenius et al. 2003). People are exposed to BFRs in the food chain (mainly from fish and other food of animal origin), but also to BFRs from the air. It means that people particularly at risk of excessive exposure to BFRs and PBDEs are workers servicing or recycling computers and electronic equipment, workers in the rubber industry who add PBDEs to rubber products, and employees in plants manufacturing electrical cables with insulation layers that contain large amounts of these substances (reviewed in $\mathrm{Sjödin} \mathrm{et} \mathrm{al.} \mathrm{2003).}$

\section{Trends in BFRs contamination of the environment and future prospects}

Because of the ubiquitous character of PBDEs in the environment and their proven toxic effects, their use in Europe is largely regulated. As mentioned earlier, the industry used to use mainly penta- and octaBDE mixtures. Directive 2003/11/EC of the European Parliament and of the Council of 6 February 2003 amending Council Directive 76/769 EEC relating to the restrictions on the marketing and use of certain dangerous substances and preparations prohibits the marketing and use of pentabromodiphenyl ether and octabromodiphenyl ether mixtures and products that contain any one of these mixtures. The two institutions decided to adopt the measures on the strength of the opinions of the European Commission Scientific Committee on Toxicity, Ecotoxicity and the Environment (CSTEE) of 4 February 2000, 19 June 2000 and 31 October 2002. The Directive 2003/11/EC also instructs member countries to harmonize their legislation with measures set down in the directive by 15 August 2004 (The European Parliament and the Council of the European Union 2003b). It is also necessary to mention Directive 2002/95/EC of 27 January 2003 on the restriction of use of certain hazardous substances in electrical and electronic equipment, which assumed that marketing of only PBDE-free electrical and electronic equipment will be allowed after 1 July 2006 in EU member countries (The European Parliament and the Council of the European 
Union 2003a). Risk assessment results were, however, re-examined, and a decision was taken to allow the use of electrical and electronic equipment containing decaBDE even after that date (The Commission of the European Communities 2005).

In spite of all the measures taken in recent years, PBDEs are nowadays widespread all over the world. The presence of PBDEs has been demonstrated even in samples coming from regions with no apparent industrial load. Christensen et al. (2002) and Vorkamp et al. (2004) have detected PBDEs in animals from Greenland.

Temporal trends in PBDE contamination of the environment are outlined in Figs. 1 and 2. They clearly show a decline in PBDE concentrations in living organisms coming from the European continent in recent years. Reporting on the 1972 - 1997 period, Meiron y té et al. (1999) concluded that PBDE concentrations in breast milk of Swedish mothers continued to increase. Results of another study by the same authors, however, indicate that in the period that followed PBDEs concentrations began to decrease (Meironyté-Guvenius et al. 2003). It has also been reported that starting approximately in the early 1990s, PBDE concentrations in tissues of the pike (Esox lucius) from the Lake Bolmen in Sweden began to decrease slightly (Kierkega ard et al. 2004) (Fig. 1). A similar trend has also been

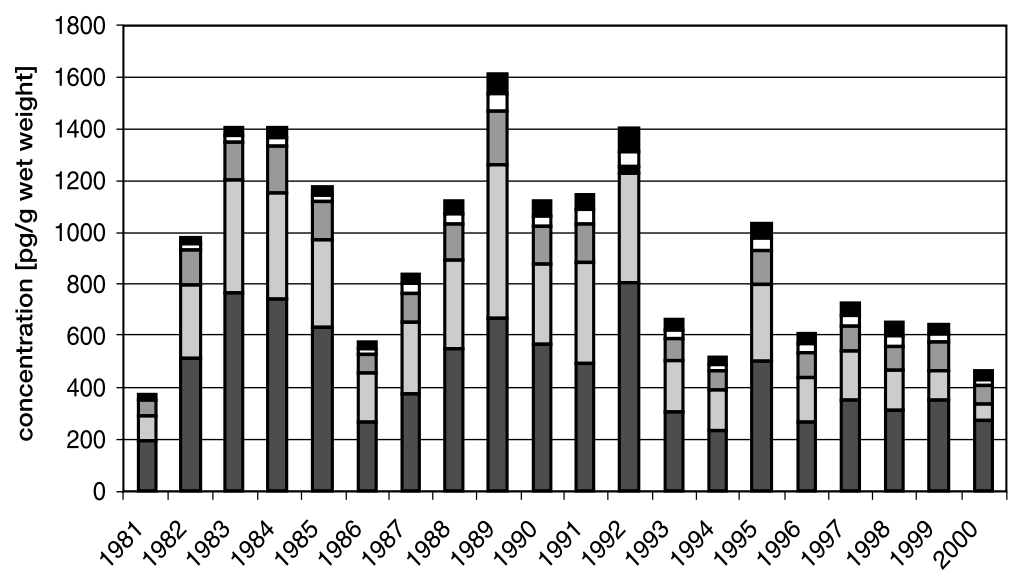

口BDE-47 $\square$ BDE-99 $\square$ BDE-100 $\square \mathrm{BDE}-153$ BDE-154

Fig. 1. Temporal trends in the concentrations of several PBDE congeners in pike from Lake Bolmen (Sweden) (adapted from Kierkegaard et al. 2004)

demonstrated by Sellström et al. (2003) investigating PBDE concentrations in eggs of guillemots (Uria algae). The authors noted a sharp decline in PBDE concentrations starting in the late 1980s. It needs to be emphasized that although concentrations of tetra- and pentaPBDE congeners in eggs of guillemots did decrease considerably, there has been no decrease in HBCD concentrations ( Sellström et al. 2003) (Fig. 2). It should also be borne in mind that the authors investigated only tetra- and pentaPBDE congeners. In recent years, the manufacture and the use of pentaBDE mixtures in Europe have been first restricted and subsequently even banned. It may therefore be assumed that while concentrations of PBDE congeners with a smaller number of bromine atoms detected in living organisms will continue to decrease, the coming years may see a relative increase in concentrations of highly brominated PBDEs (e.g. BDE-183 and BDE-209).

Although BFRs have been in the centre of attention of the research community for a relatively long period of time, there are still many mechanisms of action of these substances 


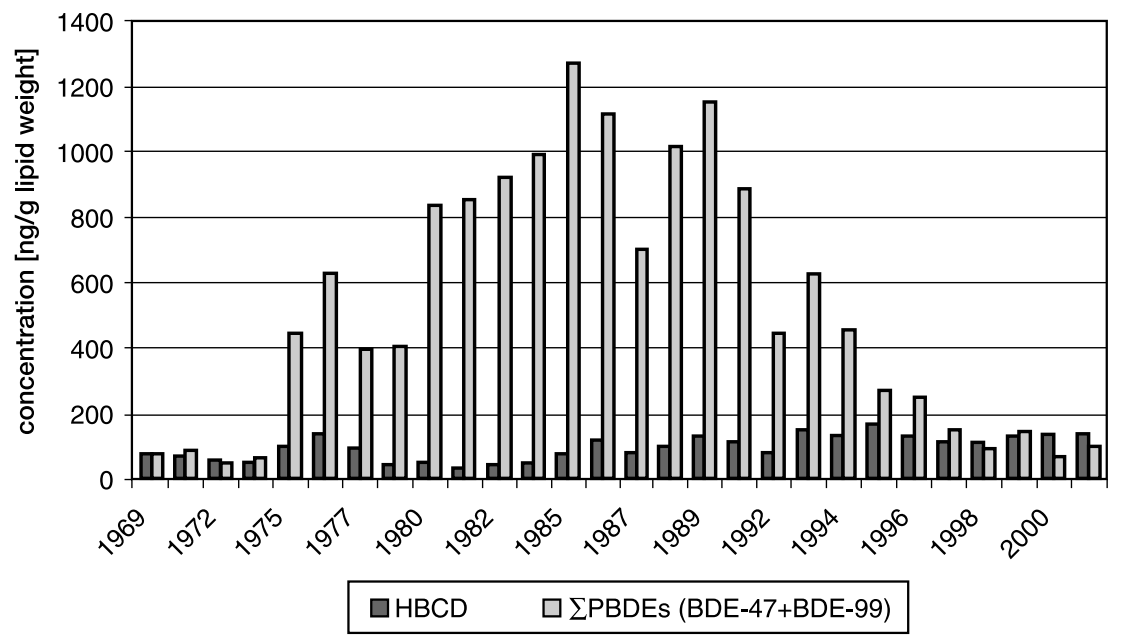

Fig. 2. Temporal trends in the concentrations of several PBDE congeners and HBCD in guillemot eggs from Sweden (adapted from Sellström et al. 2003)

that have not been explained yet. In spite of that, we are justified in saying that BFRs are among significant contaminants of the environment. To assess health risks posed by BFRs, further research into the extent to which these substances contaminate the environment and also into their toxic effects will be needed.

\section{Bromované zpomalovače hoření: zdroje a účinky - review}

Bromované zpomalovače hoření (BFRs) jsou organické látky používané v mnoha odvětvích průmyslu. Nejdůležitější skupinou BFRs jsou polybromované difenylétery (PBDEs), které $\mathrm{z}$ důvodu své perzistence $\mathrm{v}$ životním prostředí, akumulace v potravních řetězcích a toxických účinků představují potenciální nebezpečí ohrožení zdraví zvířat a člověka. Polybromované difenylétery vykazují schopnost narušení procesů hormonální regulace $\mathrm{v}$ živých organismech snižováním koncentrací thyroxinu $\mathrm{v}$ plasmě exponovaných jedinců. In vitro studie prokázaly schopnost vazby těchto látek na estrogenní či androgenní receptory. V pokusech na hlodavcích byla zjištěna také neurotoxicita některých PBDEs. Přestože je používání PBDEs v průmyslu v současnosti do značné míry regulováno, výskyt těchto látek již byl zaznamenán také v oblastech bez zjevného průmyslového zatížení např. v Grónsku. Předkládaný článek shrnuje poznatky týkající se problematiky BFRs se zaměřením na PBDEs, popisuje toxické účinky těchto látek a jejich metabolismus v živých organismech a zabývá se problematikou výskytu PBDEs v životním prostředí.

\section{Acknowledgements}

This study has been co-funded by the Internal Grant Agency of the University of Veterinary and Pharmaceutical Sciences Brno, Project No. 59/05. The study is part of the long-term research project MSM 6215712402.

\section{References}

ALLCHIN CR, LAW RJ, MORRIS S 1999: Polybrominated diphenylethers in sediments and biota downstream of potential sources in the UK. Environ Pollut 105: 197-207

AKUTSU K, KITAGAWA M, NAKAZAWA H, MAKINO T, IWAZAKI K, ODA H, HORI S 2003: Time-trend (1973 - 2000) of polybrominated diphenyl ethers in Japanese mother's milk. Chemosphere 53: 645-654 
BOON JP, VAN ZANDEN JJ, LEWIS WE, ZEGERS BN, GOKS ØYR A, ARUKWE A 2002: The expression of CYP1A, vitellogenin and zona radiata proteins in Atlantic Salmon (Salmo salar) after oral dosing with two commercial PBDE flame retardant mixtures: absence of short-term response. Mar Environ Res 54: 719-724

BRANCHI I, ALLEVA E, COSTA LG 2002: Effects of perinatal exposure to a polybrominated diphenyl ether (PBDE 99) on mouse neurobehavioral development. Neurotoxicology 23: 375-384

BROMINE SCIENCE AND ENVIRONMENTAL FORUM (BSEF) 2005: www.bsef.com (visited 15.2. 2006).

CHEN G, BUNCE NJ 2003: Polybrominated diphenylethers as Ah receptor agonists and antagonists. Toxicol Sci 76: $310-320$

COVACI A, GHEORGHE A, HULEA O, SCHEPENS P 2006: Levels and distribution of organochlorine pesticides, polychlorinated biphenyls and polybrominated diphenyl ethers in sediments and biota from the Danube Delta, Romania. Environ Pollut 140: 136-149

DARNERUD PO, ERIKSEN GS, JÓHANNESSON T, LARSEN PB, VILUKSELA M 2001: Polybrominated diphenyl ethers: occurrence, dietary exposure, and toxicology. Environ Health Perspect 109 (Suppl. 1): 49-68

ELJARRAT E, DE LA CAL A, RALDUA D, DURAN C, BARCELÓ D 2005: Brominated flame retardants in Alburnus alburnus from Cinca River Basin (Spain). Environ Pollut 133: 501-508

ERDOGRUL Ö, COVACI A, SCHEPENS P 2005: Levels of organochlorine pesticides, polychlorinated biphenyls and polybrominated diphenyl ethers in fish species from Kahramanmaras, Turkey. Environ Int 31: 703-711

ERIKSSON P, VIBERG H, JAKOBSSON E, ÖRN U, FREDRIKSSON A 2002: A brominated flame retardant 2,2',4,4',5-pentabromodiphenyl ether: uptake, retention and induction of neurobehavioral alterations in mice during a critical phase of neonatal brain development. Toxicol Sci 67: 98-103

FÄNGSTRÖM B, STRID A, ATHANASSIADIS I, GRANDJEAN P, WEIHE P, BERGMAN A 2004: A retrospective time trend study of PBDEs and PCBs in human milk from the Faroe Islands. Organohalogen Compounds 66: 2829-2833

FOWLES JR, FAIRBROTHER A, BAECHER-STEPPAN L, KERKVLIET NI 1994: Immunologic and endocrine effects of the flame-retardant pentabromodiphenyl ether (DE-71) in C57BL/6J mice. Toxicology 86: 49-61

HAKK H, LARSEN G, BERGMAN A, ÖRN U 2000: Metabolism, excretion and distribution of the flame retardant tetrabromobisphenol-A in conventional and bile-duct cannulated rats. Xenobiotica 30: 881-890

HALLGREN S, SINJARI T, HAKANSSON H, DARNERUD PO 2001: Effects of polybrominated diphenyl ethers (PBDEs) and polychlorinated biphenyls (PCBs) on thyroid hormone and vitamin A levels in rats and mice. Arch Toxicol 75: 200-208

HOLM G, LUNDSTRÖM J, ANDERSON T, NORRGREN L 1994: Influences of halogenated organic substances on ovarian development and hepatic EROD activity in the three-spined stickleback, Gastrosteus aculeatus and rainbow trout, Oncorhynchus mykkis. Aquat Toxicol 29: 241-256

ISOSAARI P, LUNDEBYE A-K, RITCHIE G, LIE Ø, KIVIRANTA H, VARTIAINEN T 2005: Dietary accumulation efficiencies and biotransformation of polybrominated diphenyl ethers in farmed Atlantic salmon (Salmo salar). Food Addit Contam 22: 829-837

JASPERS V, COVACI A, MAERVOET J, DAUWE T, VOORSPOELS S, SCHEPENS P, EENS M 2005: Brominated flame retardants and organochlorine pollutants in eggs of little owls (Athene noctua) from Belgium. Environ Pollut 136: 81-88

JOHNSON A, OLSON N 2001: Analysis and occurrence of polybrominated diphenyl ethers in Washington State freshwater fish. Arch Environ Contam Toxicol 41: 339-344

KALANTZI OI, MARTIN FL, THOMAS GO, ALCOCK RE, TANG HR, DRURY SC, CARMICHAEL PL, NICHOLSON JK, JONES KC 2004: Different levels of polybrominated diphenyl ethers (PBDEs) and chlorinated compounds in breast milk from two U.K. regions. Environ Health Perspect 112: 1085-1091

KAZDA R, HAJŠLOVÁ J, POUSTKA J, ČAJKA T 2004: Determination of polybrominated diphenyl ethers in human milk samples in the Czech Republic. Comparative study of negative chemical ionisation mass spectrometry and time-of-flight high-resolution mass spectrometry. Anal Chim Acta 520: 237-243

KIERKEGAARD A, BIGNERT A, SELLSTRÖM U, OLSSON M, ASPLUND L, JANSSON B, DE WIT CA 2004: Polybrominated diphenyl ethers (PBDEs) and their methoxylated derivatives in pike from Swedish waters with emphasis on temporal trends, 1967 - 2000. Environ Pollut 130: 187-198

KUIPER RV, BERGMAN A, VOS JG, VAN DEN BERG M 2004: Some polybrominated diphenyl ether (PBDE) flame retardants with wide environmental distribution inhibit TCDD-induced EROD activity in primary cultured carp (Cyprinus carpio) hepatocytes. Aquat Toxicol 68: 129-139

KURIYAMA SN, TALSNESS CE, GROTE K, CHAHOUD I 2005: Developmental exposure to low-dose PBDE99: effects on male fertility and neurobehavior in rat offspring. Environ Health Perspect 113: 149-154

LAW RJ, ALAEE M, ALLCHIN CR, BOON JP, LEBEUF M, LEPOM P, STERN GA 2003: Levels and trends of polybrominated diphenylethers and other brominated flame retardants in wildlife. Environ Int 29: 757-770

LIND Y, DARNERUD PO, ATUMA S, AUNE M, BECKER W, BJERSELIUS R, CNATTINGIUS S, GLYNN A 2004: Polybrominated diphenyl ethers in breast milk from Uppsala County, Sweden. Environ Res 93: 186-194

LINDBERG P, SELLSTRÖM U, HÄGGBERG L, DE WIT CA 2004: Higher brominated diphenyl ethers and hexabromocyclododecane found in eggs of peregrine falcons (Falco peregrinus) breeding in Sweden. Environ Sci Technol 38: 93-96 
MAZDAI A, DODDER NG, PELL ABERNATHY M, HITES RA, BIGSBY RM 2003: Polybrominated diphenyl ethers in maternal and fetal blood samples. Environ Health Perspect 111: 1249-1252

MEERTS IATM, VAN ZANDEN JJ, LUIJKS EAC, VAN LEEUWEN-BOL I, MARSH G, JAKOBSSON E, BERGMAN A, BROUWER A 2000: Potent competitive interactions of some brominated flame retardants and related compounds with human transthyretin in vitro. Toxicol Sci 56: 95-104

MEERTS IATM, LETCHER RJ, HOVING S, MARSH G, BERGMAN A, LEMMEN JG, VAN DER BURG B, BROUWER A 2001: In vitro estrogenicity of polybrominated diphenyl ethers, hydroxylated PBDEs, and polybrominated bisphenol A compounds. Environ Health Perspect 109: 399-407

MEIRONYTÉ D, NORÉN K, BERGMAN A 1999: Analysis of polybrominated diphenyl ethers in Swedish human milk A time-related trend study, 1972-1997. J Toxicol Environ Health 58: 329-341

MEIRONYTÉ GUVENIUS D, ARONSSON A, EKMAN-ORDEBERG G, BERGMAN A, NORÉN K 2003: Human prenatal and postnatal exposure to polybrominated diphenyl ethers, polychlorinated biphenyls, polychlorobiphenylols, and pentachlorophenol. Environ Health Perspect 111: 1235-1241

MÖRCK A, HAKK H, ÖRN U, KLASSON-WEHLER E 2003: Decabromodiphenyl ether in the rat: absorption, distribution, metabolism, and excretion. Drug Metab Dispos 31: 900-907

NAKARI T, PESALA P 2005: In vitro estrogenicity of polybrominated flame retardants. Aquat Toxicol 74: 272-279

ÖRN U, KLASSON-WEHLER E 1998: Metabolism of 2,2',4,4'- tetrabromodiphenyl ether in rat and mouse. Xenobiotica 28: 199-211

PETTERSSON A, VAN BAVEL B, ENGWALL M, JIMENEZ B 2004: Polybrominated diphenylethers and methoxylated tetrabromodiphenylethers in cetaceans from the Mediterranean Sea. Arch Environ Contam Toxicol 47: 542-550

POLDER A, THOMSEN C, BECHER G, SKAARE JU, LØKEN K, EGGESBØ M 2004: The Norwegian human milk study HUMIS. Variations in levels of chlorinated pesticides, PCBs and PBDEs in Norwegian breast milk. Organohalogen Compounds 66: 2476-2482

REEN RK, CADWALLADER A, PERDEW GH 2002: The subdomains of the transactivation domain of the aryl hydrocarbon receptor $(\mathrm{AhR})$ inhibit $\mathrm{AhR}$ and estrogen receptor transcriptional activity. Arch Biochem Biophys 408: $93-102$

RONISZ D, FARMEN FINNE E, KARLSSON H, FÖRLIN L 2004: Effects of the brominated flame retardants hexabromocyclododecane (HBCD), and tetrabromobisphenol A (TBBPA), on hepatic enzymes and other biomarkers in juvenile rainbow trout and feral eelpout. Aquat Toxicol 69: 229-245

SAFE S 2001: Molecular biology of the Ah recetor and its role in carcinogenesis. Toxicol Lett 120: 1-7

SAMUELSEN M, OLSEN C, HOLME JA, MEUSSEN-ELHOLM E, HONGSLO JK 2001: Estrogen-like properties of brominated analogs of bisphenol A in the MCF-7 human breast cancer cell line. Cell Biol Toxicol 17: $139-151$

SANDHOLM A, EMANUELSSON B-M, KLASSON WEHLER E 2003: Bioavailability and half-life of decabromodiphenyl ether (BDE-209) in rat. Xenobiotica 33: 1149-1158

SCHECTER A, PAVUK M, PÄPKE O, RYAN JJ, BIRNBAUM L, ROSEN R 2003: Polybrominated diphenyl ethers (PBDEs) in U.S. mothers' milk. Environ Health Perspect 111: 1723-1729

SCHUHMACHER M, KIVIRANTA H, VARTIAINEN T, DOMINGO LL 2004: Concentrations of polychlorinated biphenyls (PCBs) and polybrominated diphenyl ethers (PBDEs) in breast milk of women from Catalonia, Spain. Organohalogen Compounds 66: 2560-2566

SELLSTRÖM U, BIGNERT A, KIERKEGAARD A, HÄGGBERG L, DE WIT C, OLSSON M, JANSSON B 2003: Temporal trend studies on tetra- and pentabrominated diphenyl ethers and hexabromocyclododecane in guillemot egg from the Baltic Sea. Environ Sci Technol 37: 5496-5501

SJÖDIN A, PATTERSON JR. DG, BERGMAN A 2003: A review on human exposure to brominated flame retardants - particularly polybrominated diphenyl ethers. Environ Int 29: 829-839

STAPLETON HM, ALAEE M, LETCHER RJ, BAKER JE 2004a: Debromination of the flame retardant decabromodiphenyl ether by juvenile carp (Cyprinus carpio) following dietary exposure. Environ Sci Technol 38: 112-119

STAPLETON HM, LETCHER RJ, BAKER JE 2004b: Debromination of polybrominated diphenyl ether congeners BDE 99 and BDE 183 in the intestinal tract of the common carp (Cyprinus carpio). Environ Sci Technol 38: 1054-1061

STAPLETON HM, LETCHER RJ, LI J, BAKER JE 2004c: Dietary accumulation and metabolism of polybrominated diphenyl ethers by juvenile carp (Cyprinus carpio). Environ Toxicol Chem 23: 1939-1946

STASKAL DF, DILIBERTO JJ, DEVITO MJ, BIRNBAUM LS (2005): Toxicokinetics of BDE 47 in female mice: effect of dose, route of exposure, and time. Toxicol Sci 83: 215-223

STOKER T, COOPER RL, LAMBRIGHT CS, WILSON VS, FURR J, GRAY LE 2005: In vivo and in vitro antiandrogenic effects of DE-71, a commercial polybrominated diphenyl ether (PBDE) mixture. Toxicol Appl Pharmacol 207: 78-88

SZYMAŃSKA JA, SAPOTA A, FRYDRYCH B 2001: The disposition and metabolism of tetrabromobisphenolA after a single i.p. dose in the rat. Chemosphere 45: 693-700 
THE EUROPEAN PARLIAMENT AND THE COUNCIL OF THE EUROPEAN UNION 2003a: Directive 2002/95/EC of the European Parliament and of the Council of 27 January 2003 on the restriction of the use of certain hazardous substances in electrical and electronic equipment.

THE EUROPEAN PARLIAMENT AND THE COUNCIL OF THE EUROPEAN UNION 2003b: Directive 2003/11/EC of the European Parliament and of the Council of 6 February 2003 amending for 24th time Council Directive 76/769 EEC relating to restrictions on the marketing and use of certain dangerous substances and preparations (pentabromodiphenyl ether, octabromodiphenyl ether).

THE COMMISSION OF THE EUROPEAN COMMUNITIES 2005: 2005/717/EC Commission decision of 13 October amending for the purposes of adapting to the technical progress the Annex to Directive 2002/95/EC of the European Parliament and of the Council on the restriction of the use of certain hazardous substance in electrical and electronic equipment.

TOMY GT, PALACE VP, HALLDORSSON T, BRAEKEVELT E, DANELL R, WAUTIER K, EVANS B, BRINKWORTH L, FISK AT 2004: Bioaccumulation, biotransformation, and biochemical effects of brominated diphenyl ethers in juvenile lake trout (Salvelinus namaycush). Environ Sci Technol 38: 1496-1504

VERSLYCKE TA, VETHAAK AD, ARIJS K, JANSSEN CR (2005): Flame retardants, surfactants and organotins in sediment and mysid shrimp of the Scheldt estuary (The Netherlands). Environ Pollut 136: 19-31

VIBERG H, FREDRIKSSON A, ERIKSSON P 2002: Neonatal exposure to the brominated flame retardant $2,2^{\prime}, 4,4^{\prime}, 5$ - pentabromodiphenyl ether causes altered susceptibility in the cholinergic transmitter system in the adult mouse. Toxicol Sci 67: 104-107

VIBERG H, FREDRIKSSON A, JAKOBSSON E, ÖRN U, ERIKSSON P 2003a: Neurobehavioral derangements in adult mice receiving decabrominated diphenyl ether (PBDE 209) during a defined period of neonatal brain development. Toxicol Sci 76: 112-120

VIBERG H, FREDRIKSSON A, ERIKSSON P 2003b: Neonatal exposure to polybrominated diphenyl ether (PBDE 153) disrupts spontaneous behaviour, impairs learning and memory, and decreases hippocampal cholinergic receptors in adult mice. Toxicol Appl Pharmacol 192: 95-106

WEBER H, HESEKER H 2004: Analysis of polybrominated diphenyl ethers in breast milk of German mothers Results of a pilot study. Fresen Environ Bull 13: 356-360

ZHOU T, ROSS DG, DEVITO MJ, CROFTON KM 2001: Effects of short-term in vivo exposure to polybrominated diphenyl ethers on thyroid hormones and hepatic enzyme activities in weanling rats. Toxicol Sci 61: 76-82

ZHOU T, TAYLOR MM, DEVITO MJ, CROFTON KM 2002: Developmental exposure to brominated diphenyl ethers results in thyroid hormone disruption. Toxicol Sci 66: 105-116 